Journal homepage:

http://www.jurnalmetal.or.id/index.php/jmi

p-issn : $0126-3463$

e-issn : $2548-673 \mathrm{X}$

\title{
STUDI AWAL PEMBUATAN FEEDSTOCK METAL INJECTION MOULDING MENGGUNAKAN TORQUE RHEOMETER
}

\section{PRELIMINARY RESEARCH OF FEEDSTOCK PREPARATION FOR METAL INJECTION MOLDING USING TORQUE RHEOMETER}

\author{
Eva Afrilinda, Shinta Virdhian dan Martin Doloksaribu \\ Balai Besar Logam dan Mesin, Kementrian Perindustrian \\ Jalan Sangkuriang No 12 Bandung, Jawa Barat 40135 \\ email : eva.afrilinda@kemenperin.go.id,shinta_va@gmail.go.id, martin-d@kemenperin.go.id
}

\begin{abstract}
Abstrak
Meningkatnya kebutuhan masyarakat akan alat transportasi, telekomunikasi dan peralatan kesehatan akan berdampak pada kemampuan industri dalam melakukan produksi secara efektif dan efisien. Metal Injection Moulding (MIM) merupakan solusi teknologi lanjut yang dapat digunakan untuk menghasilkan produk/komponen berukuran kecildan presisi dengan bentuk yang komplek. Persiapan feedstock (bahan baku) berperan sangat penting dalam proses MIM karena kualitas feedstock akan mempengaruhi kualitas produk akhir. Feedstock adalah campuran (mixed) antara serbuk (powder) dan pengikat (binder) yang homogen dengan rasio perbandingan tertentu dan memiliki perilaku pseudo-plastik. Pada proses MIM laju geser yang digunakan selama proses injeksi berkisar antara 100-10000 s-1 dengan viskositas maksimum sebesar 1000 Pa.s. Penelitian ini dilakukan untuk mengetahui karakterisitik rheologi feedstock melalui nilai laju geser dan viskositasnya. Hasil penelitian menunjukkan bahwa feedstock Fe$2 \% \mathrm{Ni}$ dengan binder 79\%(PW) $+20 \%$ (HDPE) $+1 \%(\mathrm{SA})$ dan feedstock $\mathrm{Fe}-2 \% \mathrm{Ni}$ dengan binder $79 \%(\mathrm{PW})$ + 20\%(EVA) + 1\%(SA) memenuhi syarat rheologi sebagai feedstock Metal Injection Molding.
\end{abstract}

Kata Kunci : feedstock, binder, mixing

\begin{abstract}
The increasing of public demand in transportation, telecommunications and medical equipment will make an impact on the industry's production ability to be more effective and efficient. Metal Injection Molding (MIM) is one of advanced technologies solution which it allows the mass production of small and precision products with a very complex shape. Feedstock (raw materials) preparation plays a very important role in the MIM process because the quality of the feedstock will affect the quality of the final product. Feedstock is a homogeneous mixture of powder and binder with a certain amount ratio and has a pseudo-plastic behavior. In MIM process, the shear rate used during the injection process around 100-10000 s with a maximum viscosity of 1000 Pa.s. This research is conducted to determine the rheological characteristics of feedstock by the value of shear rate and viscosity. The result shows that Fe-2\%Ni feedstock with $79 \%$ binder $(P W)+20 \%(H D P E)+1 \%(S A)$ and $\mathrm{Fe}-2 \% \mathrm{Ni}$ feedstock with $79 \%$ binder $(P W)+20 \%(E V A)+1 \%(S A)$ have qualified the rheology requirement as a Metal Injection Molding feedstock.
\end{abstract}

Keyword : feedstock, binder, mixing

\section{PENDAHULUAN}

Pertumbuhan industri yang sangat pesat merupakan dampak dari meningkatnya kebutuhan masyarakat akan produk yang berkualitas sehingga dibutuhkan suatu proses yang efektif dan efisien. Metal injection molding (MIM) merupakan gabungan dari proses powder metallurgy dan plastic injection molding yang diaplikasikan pada pembuatan produk/komponen yang memerlukan sifat mekanis yang tinggi (high performance), fleksibilitas desain dan 
material, permukaan akhir yang baik, jumlah produksi yang tinggi sehingga dapat mengurangi secara signifikan biaya manufaktur. Pembuatan komponen menggunakan proses MIM dapat menghasilkan produk/komponen berukuran kecil, presisi dan memiliki karakteristik near net shape dengan bentuk kompleks sehingga terkadang tidak memerlukan proses lanjutan (German 2011).

MIM sebagai salah satu advanced tecnology untuk membuat produk/komponen yang diaplikasikan pada beberapa material maju yang sulit diproses dengan teknologi yang lain seperti pengecoran dan pemesinan.Produk MIM banyak diaplikasikan untuk peralatan kesehatan, elektronik, kedirgantaraan, otomotif, kebutuhan militer, dll. Proses MIM menggunakan bahan baku yaitu serbuk logam yang memiliki ukuran antara 5-100 $\mu \mathrm{m}$ dicampur (mixing) dengan pengikat (binder) polimer menghasilkan produk yang dinamakan pellet (feedstock). Umumnya feedstock komersial memiliki rasio perbandingan komposisi $60 \%$ serbuk logam dan 40\% binder (Hossain, dkk 2015). Bahan baku tersebut yang kemudian akan diproses untuk menghasilkan suatu produk/komponen. Akan tetapi penggunaan teknologi MIM mengalami kendala dalam pengadaan feedstock/bahan baku yang belum bisa diproduksi dalam negeri sehingga harus impor dari luar negeri.

Dari penelitian ini diharapkan Indonesia mampu memproduksi feedstock di dalam negeri sehingga dapat mengurangi ketergantungan kita terhadap bahan baku impor. Selain itu, pembuatan feedstock dalam negeri juga mampu menghemat biaya pembelian bahan baku (feedstock) sekitar 10$30 \%$ dari biaya produksi produk MIM.

Berikut beberapa perbandingan harga bahan baku serbuk logam $\mathrm{Fe}-2 \% \mathrm{Ni}$ serbuk yang dibuat dengan proses gas atomized berkisar 21 $\$ / \mathrm{kg}$ sedangkan dalam bentuk feedstock berkisar $31 \$ / \mathrm{kg}$. Harga serbuk Nikel yang dibuat dengan proses carbonyl berkisar $94 \$ / \mathrm{kg}$ sedangkan dalam bentuk feedstock berkisar 112 $\$ / \mathrm{kg}$. Untuk serbuk Titania yang di buat dengan proses gas atomized berkisar $125 \quad \$ / \mathrm{kg}$ sedangkandalam bentuk feedstock berkisar 180 $\$ / \mathrm{kg}$. Untuk harga dari sistem binder yang banyak digunakan seperti PP, PE dan EVA

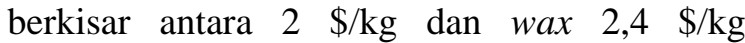
(German 2011).

\section{Proses Metal Injection Moulding (MIM)}

Secara garis besar proses produksi komponen dengan proses MIM terdiri atas empat tahapan yang secara lebih jelas dapat dilihat gambar skema seperti pada pada Gambar 1. Proses ini terdiri dari proses pencampuran (mixing), pencetakan (Injection Moulding), debinding, dan sintering. Serbuk logam dan binder dicampur dalam sebuah mixer dan kemudian dibuat pelet untuk mempermudah proses injeksi. Kemudian pelet dimasukkan ke dalam hopper mesin injection molding. Setelah itu campuran tersebut dilelehkan dan diinjeksi pada tekanan tertentu sehingga dapat mengisi rongga cetakan (proses injection molding). Hasil injection molding (green part) dihilangkan pengikatnya secara kimiawi dan heat treatment. Hasil benda setelah di debinding dinamakan brown part.

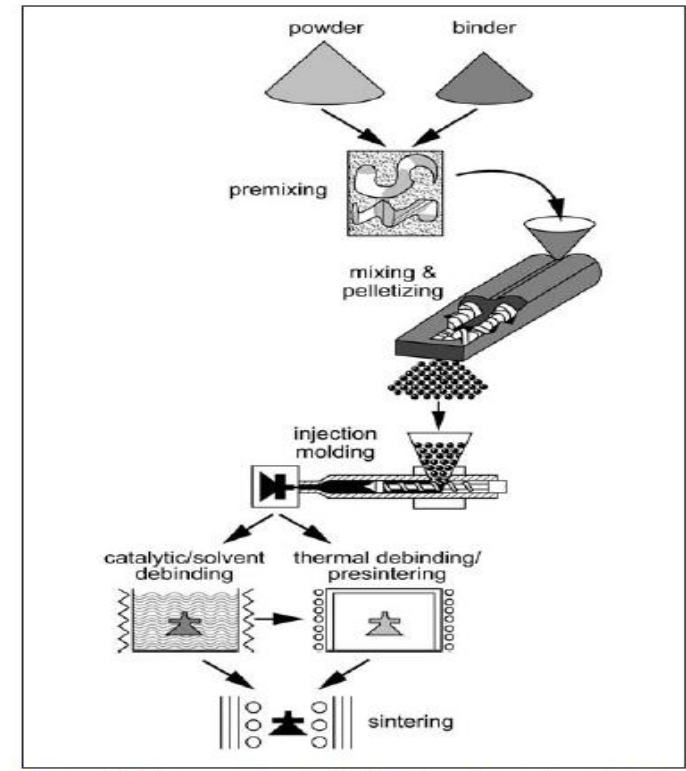

Gambar 1. Skema MIM (German 2011)

Kemudian dilakukan proses sintering untuk memadatkan dan meningkatkan kekuatan dari serbuk logam. Sintering dilakukan pada temperatur di bawah temperatur lebur material. Pada waktu proses sintering terjadi perpindahan atom secara difusi sehingga serbuk akan menyatu dan pori-pori antar serbuk akan mengecil. Setelah proses sintering, produk akan menyusut sehingga dimensi produk akan berkurang 12-20\% tergantung dari komposisi serbuk dan pengikatnya. Berat jenis produk setelah 
sintering adalah 97-99.5\% dari berat jenis material. Sifat kimia dan mekanik dari produk MIM dapat dibandingkan dengan material hasil tempa (wrought material) (Virdhian and Pujianto 2014).

\section{Raw Material}

Serbuk logam yang digunakan pada proses MIM umumnya berukuran $\leq 45 \mu \mathrm{m}$ (Heaney 2012), dimana pengunaannya tergantung pada melting temperature, reaktivitas partikel, ukuran partikel, bentuk partikel, kandungan paduan, kemurnian dan harganya (German 2011). Berikut beberapa contoh serbuk logam $M I M$ yang digunakan seperti yang ditunjukkan pada Tabel 1.

Tabel 1. Contoh serbuk logam yang biasa digunakan di MIM (German 2011)

\begin{tabular}{|c|c|c|c|c|}
\hline \multicolumn{5}{|c|}{ TABLE 2.1. EXAMPLLES OF POWDERS USED IN MIII } \\
\hline material & $\begin{array}{l}\text { nominal composition, } \\
\text { w'o }\end{array}$ & fabrication method & $\begin{array}{l}\text { median particle } \\
\text { size, } \mu m\end{array}$ & $\begin{array}{l}\text { apparent density, } \\
\mathrm{g}^{\mathrm{cm}} \mathrm{m}^{3}\end{array}$ \\
\hline copper & $99.5 \mathrm{CU}$ & water atomization & 14 & 33 \\
\hline iron & $98.3 \mathrm{Fe}$ & carbonil decomposition & 4 & 26 \\
\hline sleel & Fe-0.9C & carbonyl decomposition & 5 & 27 \\
\hline molydodenum & $99.81 / 10$ & oxide reduction & 3 & 2.1 \\
\hline nidkel & $99.8 \mathrm{Ni}$ & carbonyl reduction & 8 & 3.6 \\
\hline 316L stainless & Fe-19Cr.9Ni-2 Mo & gas atomization & 11 & 4.1 \\
\hline 6SO stainless' & $\mathrm{Fe}-17 \mathrm{Cr} 4 \mathrm{Ni}-4 \mathrm{Cu}$ & water atomization & 20 & 3.3 \\
\hline fitanium 64 & Ti.6AN4V & gas atomization & 32 & 2.1 \\
\hline tool steel & $\mathrm{Fe} \cdot 12 \mathrm{Cr} \cdot 1.5 \mathrm{C}$ & gas atomization & 11 & 4.3 \\
\hline tungsten & $99.5 \mathrm{~W}$ & coide reduction & 2 & 3.0 \\
\hline
\end{tabular}

Binder biasanya terdiri dari beberapa jenis polimer yang berfungsi sebagai penjaga bentuk (shape retention) selama debinding, low viscosity material untuk menurunkan viskositas, dan sedikit zat aditif untuk meningkatkan wetability campuran. Binder sangat berpengaruh pada kerapatan partikel, aglomerasi, rheologi, pencetakan, debinding, akurasi dimensi, cacat, dan komposisi kimia produk akhir (Enneti, R.K 2012) seperti yang terlihat pada Tabel 2.
Tabel 2. Contoh binder yang biasa digunakan di MIM (German 2011)

\begin{tabular}{|l|c|c|c|c|}
\hline $\begin{array}{c}\text { Binder } \\
\text { Material }\end{array}$ & $\begin{array}{c}\mathbf{\eta}_{\mathbf{0}}, \\
\text { Pa.s }\end{array}$ & $\begin{array}{c}\mathbf{E}, \\
\mathbf{k J} / \mathbf{m o l}\end{array}$ & $\begin{array}{c}\mathbf{T}_{\mathbf{0}}, \\
\mathbf{K}\end{array}$ & $\begin{array}{c}\text { Melting } \\
{ }^{\mathbf{0}} \mathbf{C}\end{array}$ \\
\hline $\begin{array}{l}\text { Parafin } \\
\text { Wax }\end{array}$ & 0.009 & 4.4 & 373 & 60 \\
\hline $\begin{array}{l}\text { Carnauba } \\
\text { Wax }\end{array}$ & 0.021 & 12.3 & 383 & 84 \\
\hline PE Wax & 0.81 & 19 & 383 & $>100$ \\
\hline PP & 420 & 33 & 503 & $140-200$ \\
\hline $\begin{array}{l}\text { Strearic } \\
\text { acid }\end{array}$ & 0.007 & & 383 & 74 \\
\hline
\end{tabular}

\section{Proses Mixing}

Mixing merupakan proses pencampuran serbuk dan binder kemudian digranulasi menjadi pelet dengan ukuran sekitar 5-7 mm. Campuran serbuk dengan binder yang berbentuk pelet inilah yang disebut dengan feedstock, yang kemudian digunakan sebagai bahan baku pada mesin injection molding. Perbandingan jumlah serbuk dengan binder tergantung pada jenis binder, jenis logam, bentuk dan ukuran serbuk. Rasio perbandingan umumnya sekitar $60 \%$ serbuk logam membutuhkan sekitar $40 \%$ binder. Beberapa faktor yang dapat mempengaruhi proses pencampuran (mixing) yaitu waktu mixing, temperatur mixing, ukuran serbuk, bentuk dan distribusi serbuk, formulasi binder, laju geser dan powder loading (Enneti, R.K 2012, Supati dkk 2014, Hossain et al. 2015). Keseragaman ukuran serbuk juga sangat menentukan karena keseragaman ukuran serbuk menentukan kepadatan (packing density) yang sangat berpengaruh pada pengurangan viskositas feedstock (Heaney 2012).

\section{Proses Injection Molding}

Proses Injection Moulding bertugas mengkonversi feedstock melalui cetakan menjadi bentuk produk dengan komponen mesin Injection Moulding seperti yang terlihat pada gambar 2. Pembuatan cetakan dirancang lebih besar dari ukuran sebenarnya. Hal ini dilakukan untuk mengkompensasi penyusutan produk setelah proses sintering. 


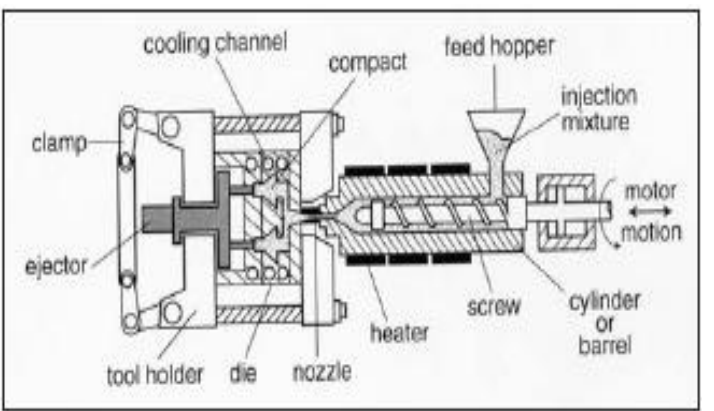

Gambar 2. Komponen mesin injeksi

(German 2011)

Selama proses pencetakan butiran/pelet feedstock disimpan di ruang temperatur kamar sebelum masuk ke dalam hopper. Hopper merupakan alat untuk memasukkan feedstock ke barel yang telah dipanaskan. Di dalam barel terdapat sebuah sekrup (screw) internal yang berfungsi mengaduk, mengompresi, dan melelehkan feedstock. Lelehan feedstock tersebut kemudian didorong ke dalam rongga cetak melalui nozel oleh feeding screw. Feeding screw harus dalam keadaan panas agar feedstock mencair dan teraduk untuk memastikan homogenitas dan tidak ada gelembung udara yang terperangkap. Feeding screw harus berbentuk lancip yang dapat memampatkan feedstock yang telah panas untuk membuang setiap udara yang terjebak. Pada daerah akhir nozzel, feedstock yang meleleh sebelum mengisi rongga cetakan sampai penuh terlebih dahulu masuk melalui sprue, runner dan gate seperti yang terlihat pada Gambar 3. Temperatur maksimum pada cetakan biasanya di bawah $190^{\circ} \mathrm{C}$. Selama proses pembekuan dalam rongga cetak, tekanan masih tetap ditahan untuk mempertahankan tekanan dalam cetakan produk. Tekanan maksimum cetakan bervariasi tergantung dengan bentuk geometri, berkisar antara 1,4 Mpa - $60 \mathrm{MPa}$ (200 - 8.500 psi). Dalam beberapa situasi, pencetakan dapat dilakukan pada tekanan rendah yaitu sekitar 0,3 MPa (45 psi) (German 2011).

Setelah produk membeku, cetakan dibuka dan produk mentah (green part) dikeluarkan dari rongga cetak dengan bantuan ejector pin, seperti yang ditunjukkan pada Gambar 4. Seringkali bekas ejector pin ini masih dapat dilihat pada produk akhir.

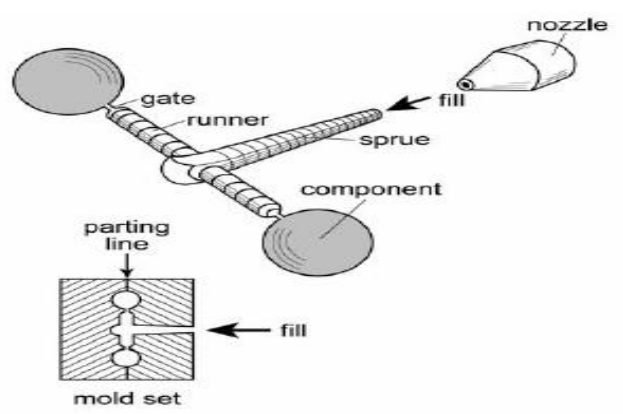

Gambar 3. Gambar bagian sprue, runner dan gate (German 2011)

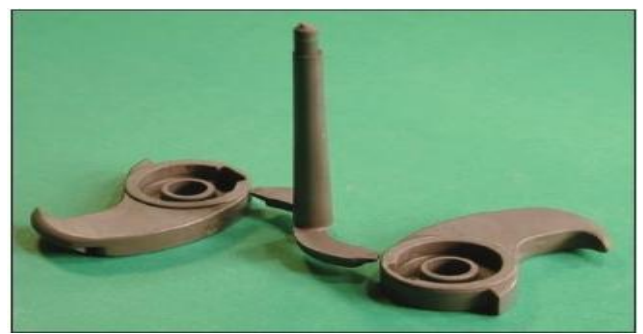

Gambar 4. Gambar bagian sprue, runner, gate dan cetakan komponen otomotif (German 2011)

\section{Proses Debinding}

Proses debinding adalah proses penghilangan binder (pengikat) dari dalam produk mentah atau green part. Debinding dapat dilakukan dengan dengan cara kimiawi (solvent debinding) dan perlakuan panas (thermal debinding), tapi umumnya lebih mudah dilakukan dengan thermal debinding. Prinsip thermal debinding yaitu menguapkan komponen binder (pengikat) dengan memanaskan dan menahannya dalam jangka waktu tertentu pada temperatur sedikit di atas temperatur dekomposisi komponen binder (pengikat) tersebut. Setiap formulasi dari binder (pengikat) memerlukan perlakuan pemanasan yang berbeda-beda sesuai dengan komponen penyusunnya. Lamanya waktu penahanan pada setiap tingkat pemanasan tergantung pada ukuran produk. Pada akhir proses debinding haruslah merupakan proses pra-sinter sehingga sudah mulai terjadi ikatan antar partikel untuk mempertahankan bentuk produk. Thermal debinding tidak dilakukan dengan pemanasan pada satu temperatur tinggi karena dapat menyebabkan binder (pengikat) terdekomposisi menjadi karbon sehingga sulit dikeluarkan dari badan produk. Binder (pengikat) pada proses MIM berbasis lilin tetapi telah banyak sistem pengikat yang berbeda yang dikembangkan. 


\section{Proses Sintering}

Proses sintering merupakan proses pemanasan yang bertujuan untuk membentuk ikatan atomik antar partikel. Proses ini menghasilkan produk dengan densitas tinggi (95-99\%) dengan porisitas pada produk mencapai $1-5 \%$. Penyusutan ukuran yang cukup besar terjadi pada proses sintering yaitu sekitar 12-20\% Temperatur pada proses sintering tergantung jenis feedstock yang digunakan. Sintering dilakukan pada atmosfer tertentu dengan mempertimbangkan kemungkinan terjadinya proses yang timbul seperti oksidasi dan reduksi. Gas Argon, Hidrogen dan Nitrogen merupakan gas yang digunakan untuk melindungi produk dari oksidasi. Gas karbondioksida, disosiasi amonia dan disosiasi gas alam merupakan gas reduktor yang mampu mereduksi oksida di permukaan produk. Faktor penting dari proses sintering adalah tingkat pemanasan, waktu sintering, temperatur sintering dan atmosfer sintering. Faktor-faktor ini dapat mempengaruhi struktur mikro, ukuran, porositas, tingkat kepadatan akhir dan kandungan nitrogen akhir dari produk.

\section{Sifat Rheologis Lelehan Feedstock}

Pengisian rongga cetak pada proses MIM ditentukan oleh karakteristik rheologi feedstock, yaitu kemampuan lelehan feedstock untuk mengalir (pourability), menyebar (spreadability) dengan merata ke seluruh bagian rongga cetakan serta memiliki kemampuan untuk di injeksi (syringability). Feedstock memiliki beberapa persyaratan yaitu:

1. Rasio perbandingan serbuk yang dibuat disesuaikan dengan volume/kapasitas mixer.

2. Memiliki hasil pencampuran yang homogen (nilai torsi yang stabil pada proses pencampuran).

3. Laju geser yang digunakan selama proses injeksi berkisar antara 100-10000 s-1 dengan viskositas maksimum sebesar 1000 Pa.s. (Supati dkk 2014).

4. Binder mudah dihilangkan pada proses debinding tanpa merusak produk (Liu dkk 2001).

Feedstock pada proses MIM pada umumnya menggunakan Non Newtonian liquids yaitu jenis pseudoplastik. Perilaku pseudoplastik dapat dilihat melalui nilai viskositas yang mengindikasikan mampu alir feedstock. Pada Gambar 5 dapat ditunjukkan perbedaan beberapa karakter viskositas cairan Non Newtonian.

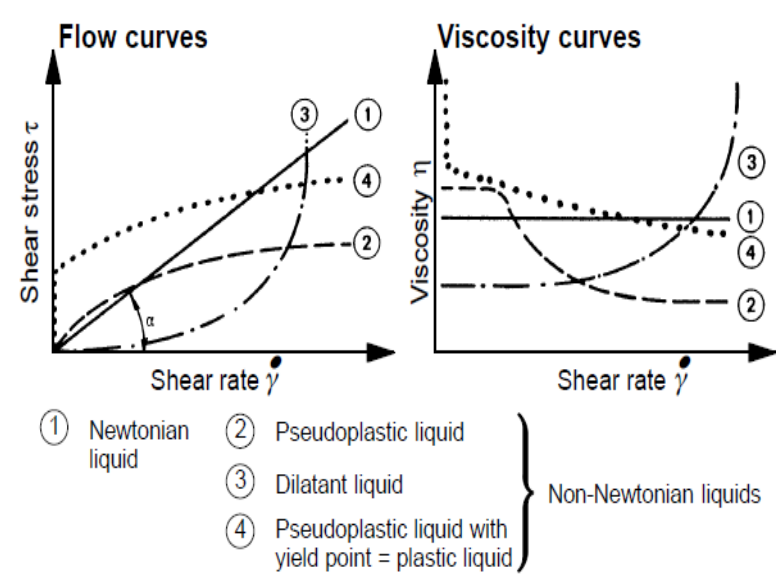

Gambar 5. Kurva aliran (flow curves) dan kurva viskositas Non Newtonian liquids (Schramm 2000)

Sifat rheologi yang paling penting pada proses MIM adalah viskositas. Viskositas merupakan sifat yang menggambarkan hubungan antara tegangan geser (shear stress) dan laju geser (shear rate). Untuk menghasilkan produk MIM yang bebas cacat maka viskositas diatur dalam rentang nilai tertentu (Khakbiz, dkk 2005). Nilai viskositas yang rendah mengindikasikan feedstock mudah mengalir, seiring meningkatnya laju geser cairan (Hossain dkk 2015). Viskositas cairan dipengaruhi oleh distribusi ukuran partikel, bentuk partikel dan massa jenis serbuk. Penambahan aditif seperti lubricant dan plasticisers dapat digunakan untuk mengurangi nilai viskositas cairan (Omar 2001).

Menurut Bousmina dkk, untuk mencari nilai shear rate dan nilai viskositas dapat digunakan analogi sederhana Couette untuk setiap silinder dan kemudian menghitung torsi keseluruhan yang diberikan oleh dua silinder pada cairan campuran. Pengaruh aperture yang ada antara dua set silinder diabaikan. Maka didapat persamaan sebagai berikut (Bousmina, dkk 1999) :

$\dot{\gamma}=16 \pi N \frac{\beta^{2}}{(1+\beta)^{2}\left(\beta^{2}-1\right)} \approx 2 \pi N / \ln (\beta)$

dimana $\dot{\gamma}=$ Shear rate $\left(\mathrm{s}^{-1}\right), \mathrm{N}=$ Rotor rotation (rpm), $\beta=$ Ratio of the mixing chamber 
Viskositas feedstock dapat dihitung dengan persamaan (Bousmina, dkk 1999):

$\eta=\frac{T}{N} \frac{\left(\beta^{2}-1\right)}{8 \pi^{2} L R_{C}^{2}\left(1+g^{2}\right)}$

dimana, $\eta=$ Viskositas (Pa.s), $\quad T=$ mixing torque (N.m), $\mathrm{L}=$ Panjang rotor $(\mathrm{m}), \mathrm{g}=$ gear ratio $N_{2} / N_{1}, R_{C}=$ Diameter Rotor

Kestabilan sifat rheologi feedstock merupakan penentu keberhasilan pada proses MIM, yang umumnya diketahui melalui analisis rheologi (Karatas, C., dkk 2004)(Krauss,V.A., dkk 2005). Beberapa penelitian yang telah dilakukan lebih difokuskan pada penelitian mengenai karakteristik sifat rheologi feedstocks melalui laju geser dan viskositasnya. Menurut Huang (Huang, B., dkk 2003) pemilihan sistem pengikat (binder) pada feedstocks dengan serbuk $\mathrm{Fe} / \mathrm{Ni}$ dapat dilihat kestabilannya dari hubungan antara laju geser dan temperatur terhadap perilaku rheologinya, yaitu viskositas feedstock. Menurut Karatas (Karatas, C., dkk 2004) dengan mempelajari sifat rheologi feedstock keramik menggunakan bahan baku polyethylene (PE) dan 3 (tiga) waxes (carnauba, bees wax dan paraffin) serta serbuk steatite, dapat ditarik kesimpulan bahwa formulasi feedstock telah berhasil dibuat sesuai dengan persyaratan dalam proses $M I M$. Kondisi ini diindikasikan dengan nilai flow behavior index $(n)$ memiliki nilai kurang dari 1 menunjukkan adanya perilaku pseudoplastic pada cairan.

Menurut Khakbiz (Khakbiz, M., dkk 2005) untuk mengevaluasi pengaruh penambahan TiC pada serbuk SS316L sebagai bahan baku feedstock, terhadap perilaku rheologi dan kestabilannya, dapat dilihat melalui capillary rheometer. Mereka menyimpulkan bahwa perilaku rheologi sangat tergantung pada komposisi campuran. Penambahan partikel TiC pada partikel serbuk stainless steel mempengaruhi viskositas feedstock pada laju geser yang rendah $<500 \mathrm{~s}^{-1}$.

Menurut penelitian yang dilakukan Krauss (Krauss, dkk 2005) ketidakstabilan feedstock akan meningkat terutama pada penambahan serbuk dalam jumlah yang besar. Adanya peningkatan laju geser dan temperatur akan berakibat pada menurunnya nilai viskositas sehingga ketidakstabilan feedstock dapat diatasi. Penggunaan capillary rheometer dalam penelitian ini dapat menganalisis perilaku rheologi feedstock dari bahan baku serbuk alumina yang terdiri dari polyethylene glycol (PEG), polyvinylbutyral (PVB) dan stearic acid $(S A)$ dengan jumlah penambahan serbuk yang berbeda. Beberapa feedstock menunjukkan perilaku pseudo-plastik $(n<0)$ dan viskositas menunjukkan ketergantungan yang tinggi terhadap laju gesernya. Hasil penelitian menunjukkan bahwa feedstock yang memiliki powder loading yang rendah memiliki perilaku rheologi yang baik.

Menurut hasil penelitian yang dilakukan oleh Faiz Ahmad (Ahmad 2005) mempelajari sifat aliran dari campuran komposit yang terdiri dari serbuk aluminum dan serat gelas yang dicampurkan dengan binder plastik. Powder loading yang optimum adalah kondisi dimana viskositas campuran komposit menurun seiring peningkatan laju gesernya. Penelitian ini mengevaluasi pengaruh powder loading dan ukuran partikel serbuk pada feedstock SS316L terhadap perilaku rheologi dan kemampuan feedstock untuk dicetak.

Menurut penelitian yang dilakukan Herranz (Herranz dkk. 2005) formulasi baru feedstock dengan bahan baku binder high density polyethylene (HDPE) dan paraffin wax $(P W)$ dikembangkan untuk memproduksi komponen M2 high speed steel menggunakan mesin metal injection moulding. Pencampuran yang homogen (miscible) antara kedua binder telah dianalisis menggunakan dynamomechanical thermal analysis (DMTA). Dari pengukuran viskositas dari campuran kedua binder yang berbeda pada laju geser yang berbeda. Kondisi ini menunjukkan formulasi yang optimum untuk proses MIM yaitu pada penggunaan 50\% HDPE. Dari pengukuran torsi pada campuran terlihat pula bahwa maksimum rasio penggunaan serbuk yang digunakan yaitu sekitar $70 \%$.

Menurut Liu (Liu, dkk 2001) untuk pembuatan komponen yang berukuran mikro telah dilakukan penelitian formulasi komposisi dengan menggunakan sistem binder multi komponen yaitu Paraffin Wax $(P W)$, Ethylene Vinyl Acetate (EVA) dan High Density Polyethylene (HDPE). Dalam penelitian ini ditunjukkan bahwa penggunaan 
serbuk stainless steel 316L dengan ukuran 100x100x250 $\mu \mathrm{m}$ telah berhasil dicetak, debinding dan disinter dengan baik dengan formulasi sistem binder $20 \mathrm{wt} \%$ (PW) +40 wt.\% (EVA) + 40 wt.\% (HDPE) binder.

Dapat disimpulkan dari beberapa penelitian bahwa kandungan serbuk logam terlalu banyak akan menyebabkan viskositas bahan baku terlalu tinggi dan mengakibatkan kegagalan injeksi molding. Perilaku rheologi feedstocks sangat tergantung pada komposisi campuran sehingga adanya peningkatan laju geser dan temperatur akan berakibat pada menurunnya nilai viskositas. Berdasarkan beberapa penelitian tersebut maka dilakukan penelitian ini untuk mengetahui karakterisitik rheologi feedstock melalui nilai laju geser dan viskositasnya, dengan menggunakan bahan baku serbuk $\mathrm{Fe} 2 \% \mathrm{Ni}$ dengan 2 (dua) jenis pengikat (binder) HighDesnsity Polyethylene (HDPE) dan Ethylene Vinyl Acetate (EVA) dalam memenuhi syarat rheologi sebagai feedstock Metal Injection Molding.

\section{METODOLOGI}

\section{Flowchart Pembuatan}

Tahap-tahap pelaksanaan pembuatan feedstock menggunakan mixer test dilakukan dalam beberapa tahap sebagaimana yang dijelaskan dalam flowchart Gambar 6.

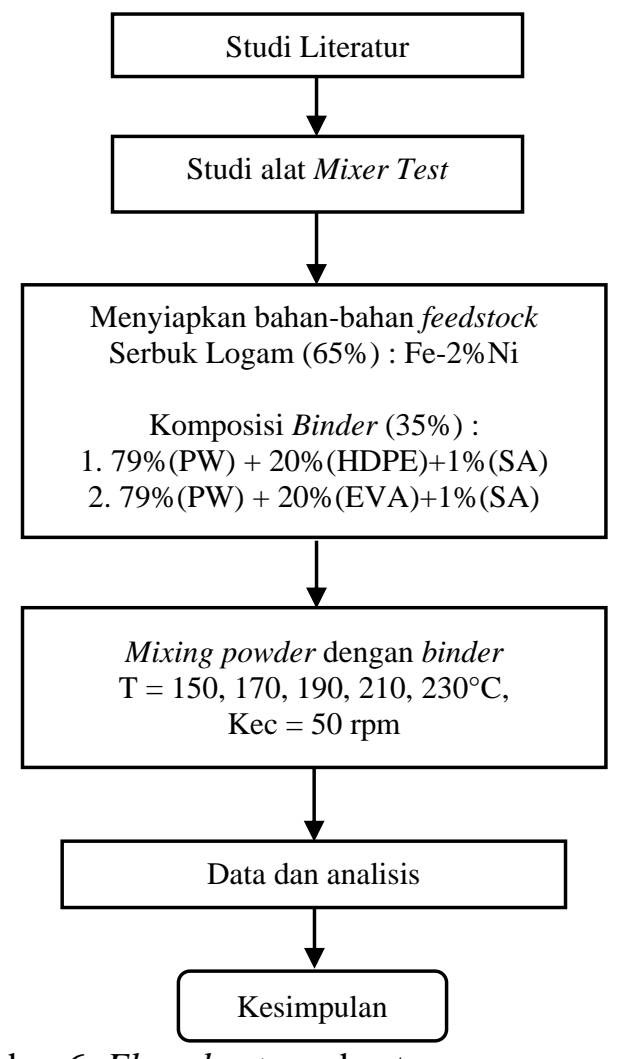

Powder

Powder yang digunakan adalah Powder Fe2\%Ni merk Epson Atmix Corporation untuk masing-masing feedstock.

\section{Binder}

Binder yang digunakan ada 2 jenis untuk masing-masing feedstock yaitu:

\section{1) Feedstock 1}

Parafin Wax (PW) 79\% + High-Desnsity Polyethylene (HDPE) $20 \%+$ Steric Acid (SA) $1 \%$.

\section{2) Feedstock 2}

Parafin Wax (PW) 79\% + Ethylene Vinyl Acetate (EVA) $20 \%$ + Steric Acid (SA) $1 \%$.

\section{Mixer Test}

Beragamnya perangkat mixer memungkinkan metode pencampuran yang berbeda akan tetapi pencampurannya harus homogen dan memiliki perilaku pseudo-plastik. Pada penelitian ini digunakan Polylab Rheo Testmixer 3000 seperti yang ditunjukkan pada Gambar 7. Spesifikasi Polylab Rheo Testmixer 3000 ditunjukkan pada Tabel 5. Jenis mixer rotor roller blade ini memiliki cara kerja yang sama dengan twin cam mixer yaitu mixer yang bergerak berlawanan arah jarum jam. Temperatur yang digunakan pada proses mixing adalah 150, 170, 180, 190, $210,230^{\circ} \mathrm{C}$. Kecepatan rotor konstan $50 \mathrm{rpm}$ dengan rasio perbandingan antara powder dan binder adalah $80 \%$ dari volume (volume total ruang adalah $310 \mathrm{~cm}^{3}$ ). Temperatur dan torsi pencampuran dimonitor sebagai output parameter.

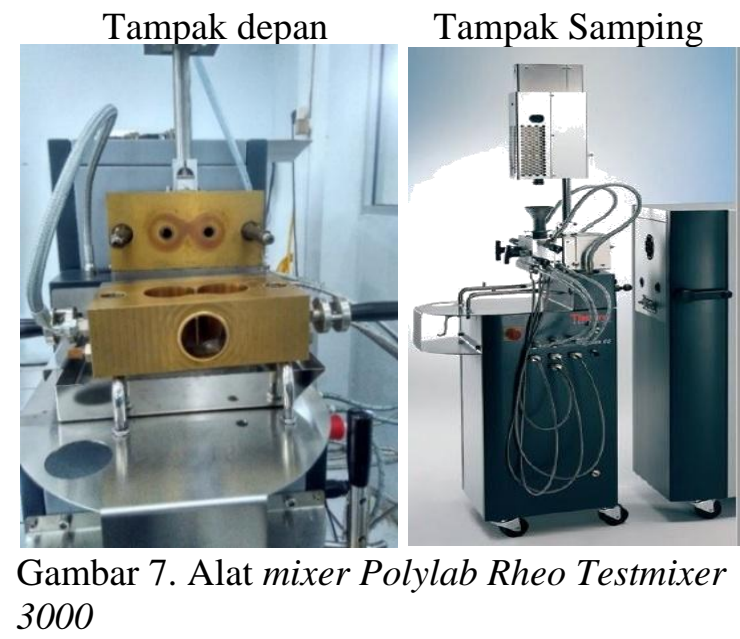


Tabel 5. Spesifikasi alat mixer Polylab RheoTestmixer 3000

\begin{tabular}{|l|l|}
\hline Item & Rheomix 3000 \\
\hline Chamber Volume & $625 \mathrm{~cm}^{3}$ \\
\hline With Rotor & $310-541 \mathrm{~cm}^{3}$ \\
\hline Material & $\begin{array}{l}\text { Stainless Steel DIN } \\
1.4301\end{array}$ \\
\hline Gear ration & $3: 2($ optional 2:3) \\
\hline Max. Speed & $250 \mathrm{~min}^{-1}$ \\
\hline Max. Torque & $300 \mathrm{Nm}$ \\
\hline Max. Temperature & $400^{\circ} \mathrm{C}$ \\
\hline Temperature & $\begin{array}{l}3 \text { zones electric } \\
\text { heating and air } \\
\text { Control }\end{array}$ \\
& \multicolumn{2}{|l}{} \\
\hline
\end{tabular}

\section{HASIL DAN PEMBAHASAN}

A. Penentuan Berat Feedstock

Rasio perbandingan komposisi yang dilakukan adalah $65 \%$ powder $\mathrm{Fe}-2 \% \mathrm{Ni}, 35 \%$ binder dengan volume Chamber $160 \mathrm{~cm}^{3}$. Berikut Persamaan 3 dan 4 yang digunakan untuk perhitungan komposisi volume powder dan binder yang digunakan serta karakteristik binder seperti yang ditunjukkan pada Tabel 6:

\section{Perhitungan Berat Powder}

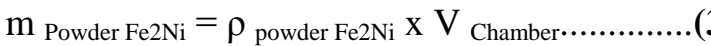

Dimana $\mathrm{m}=$ Massa $(\mathrm{g}), \rho=$ Massa Jenis $\mathrm{g} / \mathrm{cm}^{3}$ dan $\mathrm{V}=$ Volume $\left(\mathrm{cm}^{3}\right)$

\section{Perhitungan Berat Binder}

Volume Binder $=\frac{\text { Vol Binder } x \text { Vol Chamber }}{\text { Vol Powder }}$.

Tabel 6. Karakteristik komponen binder

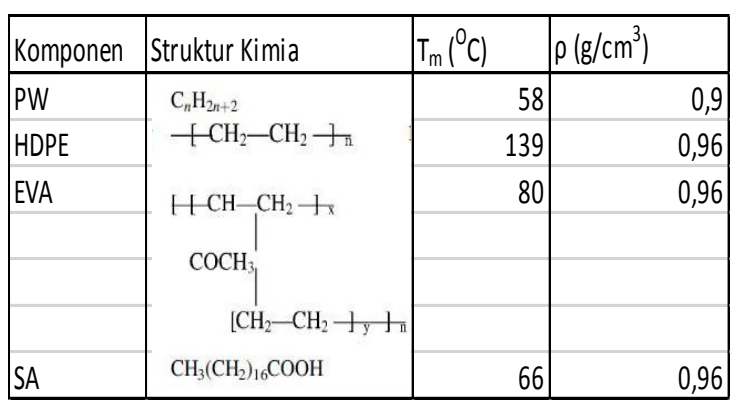

Persamaan 5 dan 6 digunakan untuk perhitungan komposisi feedstock 1 dan 2, sebagai berikut:
Perhitungan Komposisi Feedstock

$\rho_{\text {Binder }}=$

$\underline{\left(\left(79 \% x \rho_{\text {paraffin wax }}\right)+\left(20 \% x \rho_{H D P E / E V A}\right)+\left(1 \% x \rho_{S A}\right)\right)}$ 100

$\mathrm{m}_{\text {Binder }}=\rho_{\text {Binder }} \mathrm{x} \mathrm{V}$

Proses mixing dilakukan dengan kecepatan 50 rpm. Berikut data rata-rata torque pada komposisi feedstock 1 dan 2 seperti ditunjukkan pada Tabel 7.

Tabel 7. Data rata-rata torque pada komposisi feedstock 1 dan 2

\begin{tabular}{|c|c|c|c|}
\hline Kode Sampel & $\begin{array}{l}\text { Temp } \\
\left({ }^{\circ} \mathrm{C}\right)\end{array}$ & $\begin{array}{l}\text { Speed } \\
\text { (rpm) }\end{array}$ & $\begin{array}{c}\text { Mean } \\
\text { Torque } \\
\text { (N.m) }\end{array}$ \\
\hline \multirow{5}{*}{$\begin{array}{c}79 \%(\mathrm{PW})+ \\
20 \%(\mathrm{HDPE})+\mathbf{1 \%}(\mathrm{SA} \\
)\end{array}$} & 150 & 50 & 23.52 \\
\hline & 170 & 50 & 18.73 \\
\hline & 190 & 50 & 15.75 \\
\hline & 210 & 50 & 14.00 \\
\hline & 230 & 50 & 13.29 \\
\hline \multirow{5}{*}{$\begin{array}{c}79 \%(\mathrm{PW})+ \\
20 \%(\mathrm{EVA})+1 \%(\mathrm{SA})\end{array}$} & 150 & 50 & 18.85 \\
\hline & 170 & 50 & 18.57 \\
\hline & 190 & 50 & 15.75 \\
\hline & 210 & 50 & 14.00 \\
\hline & 230 & 50 & 13.29 \\
\hline
\end{tabular}

\section{B. Analisi Grafik pada Feedstock 1}

Pada Gambar 8 dan 9 terlihat grafik feedstock 1 mengalami penurunan nilai torsi seiring dengan peningkatan temperatur mixing (pencampuran). Semakin tinggi temperatur mixing (pencampuran) maka semakin turun nilai torsi. Penurunan nilai torsi pada temperatur $150^{\circ} \mathrm{C}$, $170^{\circ} \mathrm{C}, 190^{\circ} \mathrm{C}$ terjadi karena semakin semakin tinggi temperatur mixing (pencampuran) maka semakin banyak HDPE yang melebur meskipun belum sampai hangus terbakar. Sementara pada temperatur $210^{\circ} \mathrm{C}$ dan $230^{\circ} \mathrm{C}$ semakin banyak HDPE yang mulai terbakar atau terdegradasi akibat dipanaskan melebihi temperatur leburnya yaitu $129^{\circ} \mathrm{C}$ (Liu et al. 2001). Kondisi tersebut akan mempengaruhi nilai torsi yang dihasilkan. 
Pengaruh Temperatur vs

\section{Torque pada Feedstock 1}

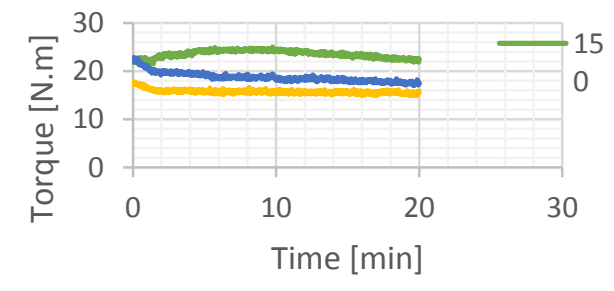

Gambar 8 Grafik Feedstock 1 pada temperatur $150^{\circ} \mathrm{C}, 170^{\circ} \mathrm{C}$ dan $190^{\circ} \mathrm{C}$

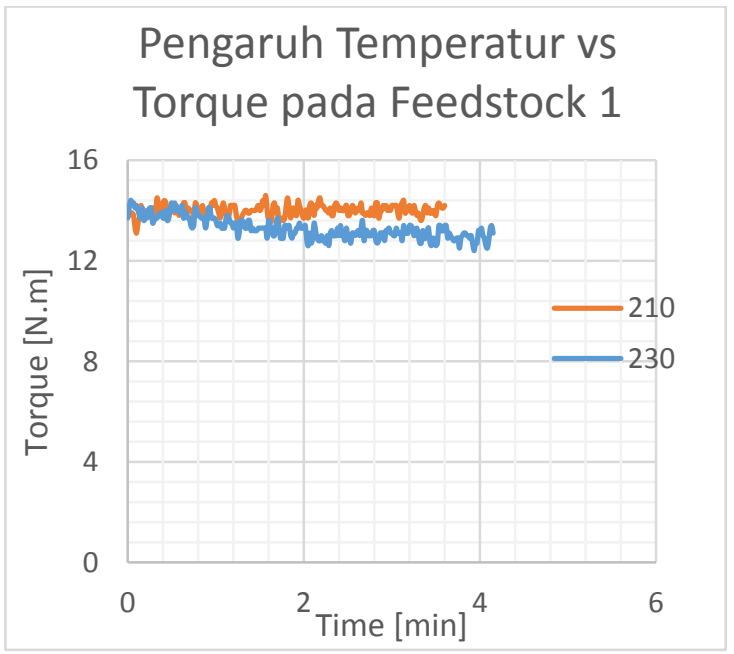

Gambar 9. Grafik Feedstock 1 pada temperatur $210^{\circ} \mathrm{C}$ dan $230^{\circ} \mathrm{C}$

\section{Analisi Grafik pada Feedstock 2}

Pada Gambar 10 dan 11 terlihat grafik feedstock 2 mengalami penurunan nilai torsi seiring dengan peningkatan temperatur mixing (pencampuran). Semakin tinggi temperatur mixing (pencampuran) maka semakin turun nilai torsi. Penurunan nilai torsi pada temperatur $150^{\circ} \mathrm{C}, 170^{\circ} \mathrm{C}, 190^{\circ} \mathrm{C}$ terjadi karena semakin semakin tinggi temperatur mixing (pencampuran) maka semakin banyak EVA yang melebur meskipun EVA belum sampai hangus terbakar. Sementara pada temperatur $210^{\circ} \mathrm{C}$ dan $230^{\circ} \mathrm{C}$ semakin banyak EVA yang mulai terbakar atau terdegradasi akibat dipanaskan melebihi temperatur leburnya yaitu $85^{\circ} \mathrm{C}$ (Liu et al. 2001). Kondisi tersebut akan mempengaruhi nilai torsi yang dihasilkan.

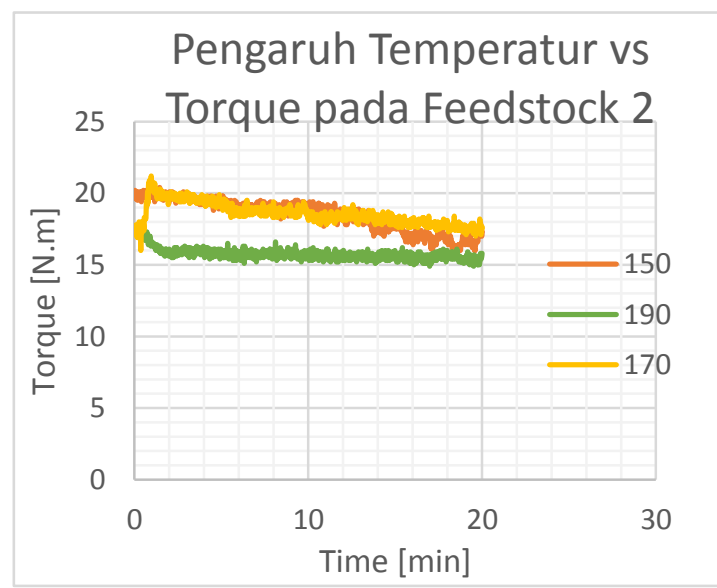

Gambar 10. Grafik Feedstock 2 pada temperatur $150^{\circ} \mathrm{C}, 170^{\circ} \mathrm{C}$ dan $190^{\circ} \mathrm{C}$

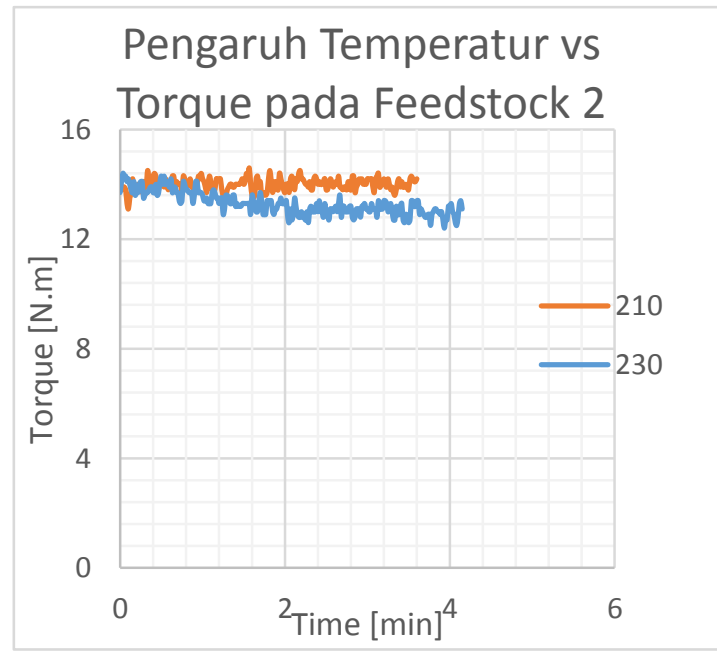

Gambar 11. Grafik Feedstock 2 pada temperatur $210^{\circ} \mathrm{C}$ dan $230^{\circ} \mathrm{C}$

\section{Data Laju Geser (Shear Rate) dan Viskositas}

\section{Perhitungan shear rate}

Untuk mengetahui laju geser (shear rate) digunakan persamaan sebagai berikut (Bousmina, dkk 1999):

$\dot{\gamma}=16 \pi N \frac{\beta^{2}}{(1+\beta)^{2}\left(\beta^{2}-1\right)} \approx 2 \pi N / \ln (\beta)$

dimana $\dot{\gamma}=$ Shear rate $\left(\mathrm{s}^{-1}\right), \mathrm{N}=$ Rotor rotation $(\mathrm{rpm}), \beta=$ Ratio of the mixing chamber 


\section{Perhitungan viskositas}

Viskositas feedstock dapat dihitung dengan persamaan sebagai berikut (Bousmina, dkk 1999) :

$\eta=\frac{T}{N} \frac{\left(\beta^{2}-1\right)}{8 \pi^{2} L R_{C}^{2}\left(1+g^{2}\right)}$

Dimana, $\eta=$ Viskositas (Pa.s), $\quad T=$ mixing torque (N.m), $\mathrm{L}=$ Panjang rotor $(\mathrm{m}), \mathrm{g}=$ gear ratio $N_{2} / N_{1}, R_{c}=$ Diameter Rotor

Dari hasil perhitungan dengan persamaan 1 dan 2 didapatkan data seperti yang ditunjukkan pada Tabel 8.

Tabel 8. Data Laju Geser (Shear Rate) dan Viskositas

\begin{tabular}{|c|c|c|c|c|c|}
\hline Kode & $\begin{array}{c}\text { Temp } \\
\left({ }^{\circ} \mathrm{C}\right)\end{array}$ & $\begin{array}{l}\text { Torsi } \\
\text { Rata- } \\
\text { Rata } \\
\text { (N.m) }\end{array}$ & $\begin{array}{c}\text { Kec } \\
(\mathbf{r p m})\end{array}$ & $\begin{array}{c}\text { Laju } \\
\text { Geser } \\
\left(\mathbf{s}^{-1}\right)\end{array}$ & $\begin{array}{l}\text { Viskosit } \\
\text { as (Pa.s) }\end{array}$ \\
\hline \multirow{5}{*}{$\begin{array}{c}79 \%(\text { PW })+ \\
20 \%(\text { HDPE) } \\
+1 \%(\text { SA })\end{array}$} & 150 & 23.52 & 50 & 2020.83 & 10.37 \\
\hline & 170 & 18.73 & 50 & 2020.83 & 8.26 \\
\hline & 190 & 15.75 & 50 & 2020.83 & 6.94 \\
\hline & 210 & 14.00 & 50 & 2020.83 & 6.17 \\
\hline & 230 & 13.29 & 50 & 2020.83 & 5.86 \\
\hline \multirow{5}{*}{$\begin{array}{c}79 \%(\text { PW })+ \\
20 \%(\text { EVA })+ \\
1 \% \text { (SA) }\end{array}$} & 150 & 18.85 & 50 & 2020.83 & 8.31 \\
\hline & 170 & 18.57 & 50 & 2020.83 & 8.19 \\
\hline & 190 & 15.75 & 50 & 2020.83 & 6.94 \\
\hline & 210 & 14.00 & 50 & 2020.83 & 6.17 \\
\hline & 230 & 13.29 & 50 & 2020.83 & 5.86 \\
\hline
\end{tabular}

\section{E. Analisis Grafik Laju Geser (Shear Rate) dan Viskositas}

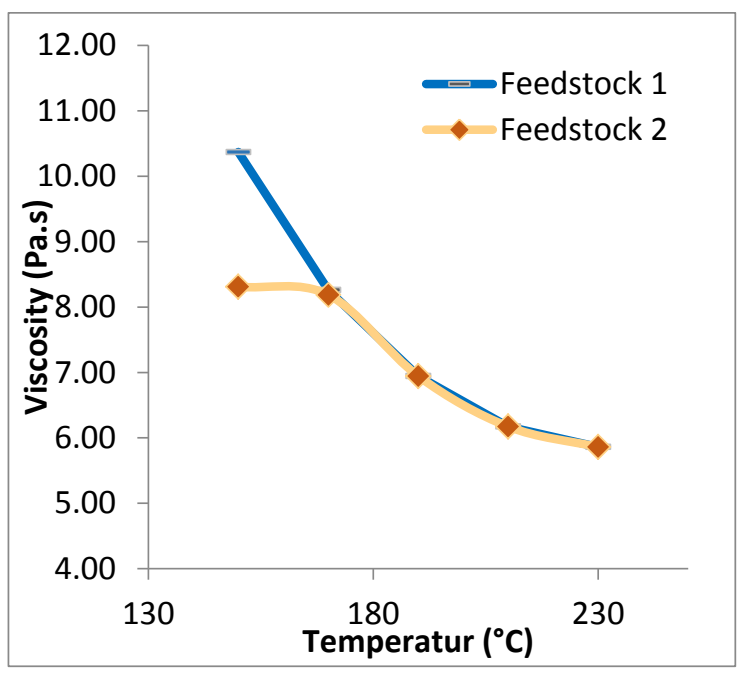

Gambar 12. Grafik hubungan antara temperatur dan viskositas feedstock 1 dan 2
Pada grafik diatas terlihat bahwa semakin tinggi laju geser (shear rate) dan temperatur mixing maka semakin menurun viskositas yang dimiliki feedstock. Hal tersebut menandakan bahwa lelehan Feedstock 1 $(79 \% \mathrm{PW}+20 \% \mathrm{HDPE}+1 \% \mathrm{SA})$ dan feedstock 2 $(79 \% \mathrm{PW}+20 \% \mathrm{EVA}+1 \% \mathrm{SA})$ termasuk jenis fluida non-newtonian yang bersifat pseudoplastic. Penurunan viskositas akibat kenaikan tegangan geser, terjadi karena adanya mekanisme pengadukan yang menyebabkan polimer tidak saling bertautan. Semakin tinggi kecepatan pengadukan maka polimer dalam hal ini pengikat (binder) menempatkan dirinya pada arah yang diberikan oleh mixer. Kondisi ini menimbulkan terjadinya internal resistance pada fluida sehingga viskositas mengalami penurunan.

Seperti pada penelitian yang dilakukan Krauss (Krauss, dkk 2005) adanya peningkatan laju geser dan temperatur akan berakibat pada menurunnya nilai viskositas sehingga ketidakstabilan feedstock dapat diatasi.

Pembuatan formulasi Feedstock 1 (79\%PW+20\%HDPE+1\%SA) dan Feedstock 2 $(79 \% \mathrm{PW}+20 \% \mathrm{EVA}+1 \% \mathrm{SA})$ telah sesuai dengan syarat karakteristik rheologi feedstock untuk proses metal injection molding. Hal ini terlihat dari nilai laju geser (shear rate) yang dihasilkan pada Feedstock 1 (79\%PW +20\%HDPE + 1\%SA) dan Feedstock 2 $(79 \% \mathrm{PW}+20 \% \mathrm{EVA}+1 \% \mathrm{SA})$ masih berada dalam rentang laju geser yang dipersyaratkan dalam proses injeksi yaitu antara 100-10000 s $\mathrm{s}^{-1}$ (Supati, dkk 2000). Nilai tersebut sangat dipengaruhi oleh kecepatan dan temperatur pencampuran mixing. Nilai viskositas pada Feedstock 1 (79\%PW +20\%HDPE + 1\%SA) dan Feedstock $2(79 \% \mathrm{PW}+20 \% \mathrm{EVA}+$ 1\%SA) memiliki viskositas dibawah 1000 Pa.s. Hal ini menunjukkan viskositas pada feedstock 1 dan 2 memiliki viskositas yang sesuai dengan viskositas yang dipersyaratkan dalam proses MIM. Nilai viskositas sangat dipengaruhi oleh nilai rata-rata torque dan laju geser (shear rate) yang dihasilkan feedstock. Nilai viskositas yang rendah mengindikasikan feedstock mudah mengalir, seiring meningkatnya laju geser cairan (Hossain dkk 2015).

Penggunaan sistem binder menggunakan Paraffin Wax $(P W)$, Ethylene Vinyl Acetate (EVA) dan High Density Polyethylene 
(HDPE) telah dilakukan pula oleh Liu (Liu, dkk 2001) yang menyatakan bahwa formulasi komposisi menggunakan sistem binder multi komponen yaitu Paraffin Wax $(P W)$, Ethylene Vinyl Acetate (EVA) dan High Density Polyethylene (HDPE) dengan serbuk stainless steel 316L telah berhasil dicetak, debinding dan disinter dengan baik. Dengan formulasi sebagai berikut: $20 \mathrm{wt} . \%(\mathrm{PW})+40$ wt.\% (EVA) + 40 wt.\% (HDPE).

Penggunaan serbuk FeNi juga dilakukan penelitian oleh Huang (Huang, B., dkk 2003) yang menyatakan bahwa pemilihan sistem pengikat (binder) pada feedstocks dengan serbuk Fe/Ni dapat dilihat kestabilannya dari hubungan antara laju geser dan temperatur terhadap perilaku rheologinya, yaitu viskositas feedstock.

\section{KESIMPULAN}

Berdasarkan proses pembuatan Feedstock dan analisis yang telah dilakukan dapat diambil kesimpulan yaitu:

1) Nilai rata-rata torsi pada Feedstock 1 dan 2 akan terus menurun seiring dengan meningkatnya temperatur mixing (pencampuran).

2) Peningkatan temperatur mixing (pencampuran) menyebabkan HDPE \& EVA akan lebur dan lambat laun akan hilang (terdekomposisi) karena melebihi suhu leburnya.

3) Nilai rata-rata torsi Feedstock 1 memiliki nilai yang lebih tinggi dibandingkan nilai rata-rata torsi Feedstock 2.

4) Komposisi binder pada Feedstock 1 dan 2 telah sesuai dengan syarat karakteristik rheologi feedstock yang alirannya bersifat pseudoplastic.

5) Nilai laju geser (shear rate) yang dihasilkan pada Feedstock 1 dan 2 masih berada dalam rentang laju geser yang dipersyaratkan dalam proses injeksi yaitu antara $100-10000$ $\mathrm{s}^{-1}$.

6) Nilai viskositas pada Feedstock 1 dan 2 memiliki viskositas yang sesuai dengan viskositas yang dipersyaratkan dalam proses MIM.

7) Karakterisitik rheologi Feedstock 1 dan 2 telah memenuhi syarat rheologi sebagai feedstock Metal Injection Molding melalui nilai laju geser dan viskositasnya, sehingga dapat menjadi studi awal dalam memproduksi feedstock di dalam negeri untuk mengurangi ketergantungan kita terhadap bahan baku impor.

\section{DAFTAR PUSTAKA}

Ahmad, Faiz. 2005. "Rheology of Metal Composity Mixes for Powder Injection Molding." International Journal of Powder Metallurgy Vol. 41, N: 43-48.

Bousmina, M., A. Ait-Kadi, and J. B. Faisant. 1999. "Determination of Shear Rate and Viscosity from Batch Mixer Data." Journal of Rheology 43 (2): 415-33. doi:10.1122/1.551044.

Enneti, R.K, Dkk. 2012. "Powder Binder Formulation and Compound Manufacture in Metal Injection Moulding (MIM)."

German, Randall M. 2011 Metal Injection Moulding A Compehensif MIM Design Guide. New Jersey: Metal Powder Industries Federation.

Heaney, D.F. 2012. "Designing For Metal Injection Moulding (MIM)," 30.

Herranz, G, B Levenfeld, A Va, and J M Torralba. 2005. "Development of New Feedstock Formulation Based on High Density Polyethylene for MIM of M2 High Speed Steels." Powder Metallurgy 48 No 2: 134-38. doi:10.1179/003258905X37828.

Hossain, Altab, Imtiaz Ahmed Choudhury, Nurun Nahar, Ismail Hossain, and Azuddin Bin Mamat. 2015. "Experimental and Theoretical Investigation of PowderBinder Mixing Mechanism for Metal Injection Molding." Materials and Manufacturing Processes 30 (1): 41-46. doi:10.1080/10426914.2014.930955.

Huang, B., Liang, S., and Qu, X. 2003. "“The Rheology of Metal Injection Molding.", Journal of Materials Processing Technology Vol. 137: 132-37.

Karatas, C., Kocer, A., Unal, H.I., and Saritas, S. 2004. "Rheological Properties of Feedstocks Prepared with Steatite Powder and Polyethylene-Based Thermoplastic Binders." Journal of Materials Processing Technology Vol 152: 77-83.

Khakbiz, M., Simchi, A., and Bagheri, R. 2005. "Analysis of the Rheological Behavior 
and Stability of 316L Stainless Steel- TiC Powder Injection Molding Feedstock." Materials Science and Engineering A, Pp. 105-113, 2005 Vol. 407,.

Krauss, V. A., Pires, E. N., Klein, A. N., and Fredel,M.C. 2005. "Rheological Properties of Alumina Injection Feedstocks." Materials Research Vol. 8: 187-89.

Liu, Z Y, N H Loh, S B Tor, K A Khor, Y Murakoshi, and R Maeda. 2001. "Binder System for Micropowder Injection Molding." Elsevier, no. March: 31-38.

Omar, Mohd Afian. 2001. "The Influence of Stearic Acid on the Properties of Injection Moulding of Stainless Steel Powder." Journal of Technology Vol. 10: 37-45.

Schramm, Gebhard. 2000. A Practical Approach to Rheology and Rheometry. 2nd ed. Kalsruhe Jerman: Gabrueber haake $\mathrm{GmbH}$.

Supati, R, N H Loh, K A Khor, and S B Tor. 2000. "Mixing and Characterization of Feedstock for Powder Injection Molding Mixing and Characterization of Feedstock for Powder Injection Molding." Elsevier, no. November: 109-14. doi:10.1016/S0167-577X(00)00151-8.

Virdhian, Shinta, and Pujianto. 2014. "Pengembangan Komponen Near Net Shape Berbiaya Rendah Dengan Proses Metal Injection Molding Development of Low Cost Near Net Shape Parts." Jurnal Riset Industri Kemenperin, no. Mim: 1121.

Khakbiz, M., Simchi, A.and Bagheri, R., "Analysis of the rheological behavior and stability of $316 \mathrm{~L}$ stainless steel- TiC powder injection molding feedstock", Materials Science and Engineering A, Vol. 407, pp. 105-113, 2005

Mohd Afian Omar, "The influence of stearic acidon the properties of injection moulding of stainless steel powder" Journal of Technology, Vol. 10, Num. 2, pp.37-45,2001

Karatas, C., Kocer, A., Unal, H.I., and
Saritas,S.,"Rheological properties of feedstocks prepared with steatite powder and polyethylene-based thermoplastic binders", Journal of Materials Processing Technology, Vol 152, pp. 77-83, 2004.

Krauss, V. A., Pires, E. N., Klein, A. N., and Fredel,M.C.,"Rheological properties of alumina injection feedstocks", Materials Research, Vol. 8, Num. 2, pp. 187-189, 2005.

Huang, B., Liang, S., and Qu, X., "The rheology of metal injection molding", Journal of Materials Processing Technology, Vol. 137, pp. 132-137, 2003. 